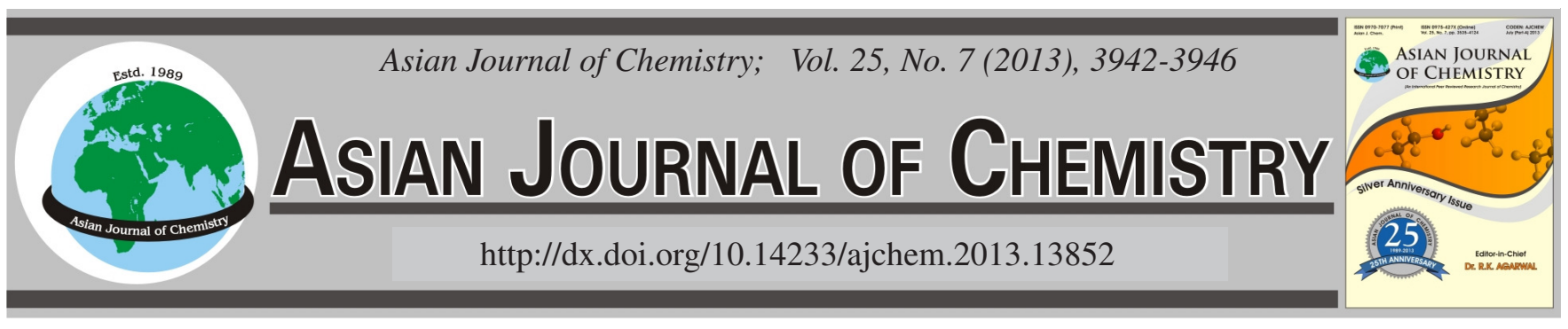

\title{
Electrokinetics Remediation of Mercury Contaminations of Bandar Imam Petrochemical Complex of Iran
}

\author{
M. Goudarzi NiK ${ }^{1, *}$, B. Shahbazi ${ }^{2}$ and S. NASERIAN ${ }^{3}$
}

\begin{abstract}
${ }^{1}$ Environmental Laboratory, Tarbiat Modares University, Tehran, Iran
${ }^{2}$ Mining Engineering Department, Tarbiat Modares University, Tehran, Iran

${ }^{3}$ Bandar Imam Petrochemical Complex, Khuzestan Province, Iran

*Corresponding author: E-mail: m_godarzi_nik@yahoo.com
\end{abstract}

\section{INTRODUCTION}

Electrokinetics has been developed from several decades. In the early stage, it was used to dewater the soil to enhance the soil's mechanical stress. Applied to soil remediation, the electrokinetics process has been regarded as an effective means to clean the sites contaminated by different pollutants such as heavy metals, organic chemicals and radio nuclide waste ${ }^{1-5}$. The main features of the electrokinetics techniques include: (1) serving either as an in situ or ex situ technology, (2) possessing with high removal efficiency for different contaminants, (3) producing an electro-osmotic flow in the heterogeneous soils, (4) applicability for the contaminated soils of low hydraulic conductivity, (5) exerting high economical effectiveness and (6) integrating with other chemical or biological technologies ${ }^{6,7}$.

Electrokinetics remediation or simply electrokinetics offers great potential for the remediation of hazardous waste sites, especially those containing fine-grained soils that have been contaminated with heavy metals. The method can be used either in situ or ex situ and essentially involves the application of a low level DC current or voltage gradient across the electrodes that encompass the contaminated soil. As a result, the contaminants are transported towards either the cathode well/ reservoir or the anode well/reservoir.
When direct electric current is passed through a soil, the ions will electro-migrate towards the electrodes. This effect is used in electrokinetics remediation because a part of the migrating ions are the contaminating heavy metals. Generally, the solid surfaces in soil carry surface charges, which are counter balanced by ions of the opposite charge forming a part of the electric double-layer. In soil, the electric resistance is lowest in the electric double-layer, where the ions accumulate as non-specific adsorbed. This means that the current tends to flow where the heavy metals are found. Other remediation methods fail in soils with a high content of clay $^{8}$. On the surface of the electrodes, the current is transformed from the electroncarried current in the electrode into ion-carried current in the electrolyte solution by the electrode processes.

$$
\begin{gathered}
\text { Cathode: } 4 \mathrm{H}_{2} \mathrm{O}+4 \mathrm{e}^{-} \rightarrow 2 \mathrm{H}_{2} \uparrow+4 \mathrm{OH}^{-} \\
\text {Anode: } 2 \mathrm{H}_{2} \mathrm{O}-4 \mathrm{e}^{-} \rightarrow \mathrm{O}_{2} \uparrow+4 \mathrm{H}^{+}
\end{gathered}
$$

These electrode processes result in an alkaline front migrating in the soil from the cathode and an acidic front migrating from the anode.

Mercury due to its high toxicity for marine fauna, is listed as a priority pollutant by the international agencies in charge of marine environmental protection. Mercury is particularly hazardous in estuaries because of their high bioproductivity ${ }^{9-13}$. 
During the last few decades, there has been a growing interest worldwide about mercury and the mechanisms that govern its concentrations in air, soil and water ${ }^{14}$. Many studies have been done on the mercury content in water because of its link to the food chain. Marinewater and sediments generally exhibit low mercury concentrations ${ }^{15,16}$. High concentrations of mercury in sediments have natural causes, as in the case of the Mediterranean $\mathrm{Sea}^{17}$, whose basin contains $c a .65 \%$ of the total world $\mathrm{Hg}$ mineral resource ${ }^{18}$ or are the result of industrial pollution ${ }^{19}$.

Asia is the world's largest and most populous continent. It covers $8.6 \%$ of the Earth's total surface area (or $29.4 \%$ of its land area). With over four billion people, it contains more than $60 \%$ of the world's current human population. Over the past three decades, remarkable economic growth has occurred in Asia, especially in the East Asia and this has put the region's natural environment at a great risk. The outbreaks of severe mercury poisoning in Minamata, Japan and Iraq in the last century had posed the shocked disaster to eco-environment system and human beings ${ }^{20-22}$.

In this research, Bandar Imam petrochemical complex (BIPC) in Khuzestan Province, Iran, is studied. The area is located in $30^{\circ} 26^{\prime} \mathrm{N}$ and $49^{\circ} 07^{\prime} \mathrm{E}$ in southern Iran in the northern part of Persian Gulf . The area is considered as part of Zagros zone, which borders western to southern Iran. Based on tectono-stratigraphic classification of Iran, three main zones as well as two suture zones can be discriminated ${ }^{23}$. The Zagros zone is very important for its hydrocarbon reserves, composed of sedimentary units and lack of igneous activity. No igneous lithology volcanic nor plutonic cropped out in the area. $\mathrm{Hg}$ mineralization is accompanied with the late stage of submarine volcanism ${ }^{24}$ but the lithology outcrop in the area does not support for such evidences. Distribution of the mercury contamination in the seaside of the Bandar Imam petrochemical complex is shown in Fig. 1 (sampling depth of $0-10 \mathrm{~cm}$ ). In this research, removal of the $\mathrm{Hg}$ contamination from the Bandar Imam petrochemical complex and artificially contaminated sand and clay (SC) samples is investigated using electrokinetics method.

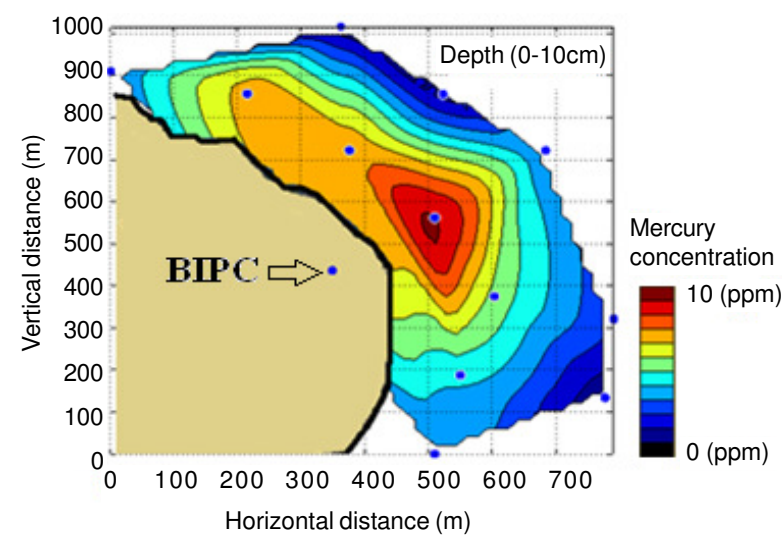

Fig. 1. Distribution of the mercury in the soil of Bandar Imam Seaside, sampling depth of $0-10 \mathrm{~cm}$ (blue circles are the sampling stations)

\section{EXPERIMENTAL}

The chemical reagents used were mercury, potassium iodide for catholyte solution $(0.4 \mathrm{M})$, local tap water for anolyte solution and nitric acid and sodium hydroxide for $\mathrm{pH}$ regulation.
Soil samples: Two different types of soil were used in the present investigation containing of Bandar Imam petrochemical complex sample and a mixture of sand and clay (SC sample) (1:2 ratio). The samples were collected and their homogenous clay fraction was separated after sieving by 10 mesh $(2000 \mathrm{~mm})$ sieve, of which the given amounts were kept in an oven for $24 \mathrm{~h}$ at $110^{\circ} \mathrm{C}$. This will remove all the possible moisture content and finally completely dry samples are obtained. A given amount of $\mathrm{Hg}$ was added to the sand and clay sample. As clay has a little buffer nature as well as fine grains, it provides us with proper conditions for electrokinetic activity. Clay was selected as it was similar in grain size with the soil materials within the Bandar Imam petrochemical complex. Soil characteristics of the Bandar Imam petrochemical complex and sand and clay samples are given in Table-1.

\begin{tabular}{lcc}
\multicolumn{3}{c}{ TABLE- 1 } \\
SOIL CHARACTERISTICS \\
\cline { 2 - 3 } \multicolumn{1}{c}{ Characteristics } & \multicolumn{2}{c}{ Samples } \\
\cline { 2 - 3 } & $\begin{array}{c}\text { Bandar Imam } \\
\text { petrochemical complex }\end{array}$ & Sand and Clay \\
\hline Liquid limit (\%) & 62 & 65 \\
Plastic limit (\%) & 19 & 18 \\
Optimum moisture (\%) & 20 & 25 \\
pH & 7.2 & 7.92 \\
Mercury content (ppm) & 110 & 98 \\
\hline
\end{tabular}

Electrokinetics cell: The research was carried out at experimental scale (Fig. 2). The cell was rectangular (with the dimensions of $28 \mathrm{~cm} \times 13 \mathrm{~cm} \times 5 \mathrm{~cm}$ ) in order to survey contaminants longitudinal transport throughout the sample so that lateral diffusion is not considered. The cell wall was made of Plexiglas with two wide blade graphite electrodes $(10 \mathrm{~cm} \times$ $7 \mathrm{~cm}$ ). Then, the voltage gradients of 1 and $1.5 \mathrm{~V} / \mathrm{cm}^{2}$ were given to both the Bandar Imam petrochemical complex and artificially contaminated sand and clay samples.
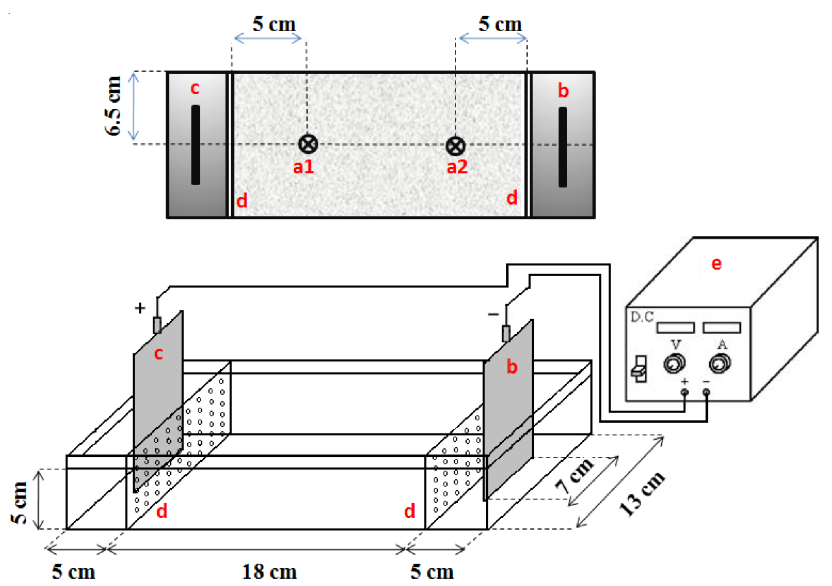

Fig. 2. A schematic of the electrokinetics cell $\left(a_{1}\right)$ Anode sampling point, $\left(\mathrm{a}_{2}\right)$ Cathode sampling point, (b) Cathode, (c) Anode, (d) SeparatorPlexiglas, (e) Rectifier

Daily sampling was accomplished from both the anode and cathode. The collected samples were then kept in an oven for $48 \mathrm{~h}$ at $45^{\circ} \mathrm{C}$. Then they were homogenously crushed and sent to $\mathrm{Hg}$ analyzer to determine their $\mathrm{Hg}$ content. Sampling was conducted at $5 \mathrm{~cm}$ distances both from the anode and cathode separators (Fig. 2). 
RESULTS AND DISCUSSION

Changes of the $\mathrm{Hg}$ concentration in the Bandar Imam petrochemical complex and sand and clay samples: Changes of $\mathrm{Hg}$ concentration during the electrokinetics experiments are given in Fig. 3. The Hg removal of the sand and clay sample was more than that of the Bandar Imam petrochemical complex sample. Primary concentration of the $\mathrm{Hg}$ within the sand and clay mixture was $98 \mathrm{ppm}$. An experiment time of 15 days was considered for the $\mathrm{Hg}$ removal. When the voltage gradient was $1 \mathrm{~V} / \mathrm{cm}^{2}$, the $\mathrm{Hg}$ concentration of the anode electrode was decreased to $39 \mathrm{ppm}$ after 15 days. Also the $\mathrm{Hg}$ concentration of the cathode electrode was increased to 179 ppm after 15 days. So the $\mathrm{Hg}$ concentration in the anode electrode was decreased to $60.2 \%$ and the $\mathrm{Hg}$ concentration in the anode electrode was increased to $82.7 \%$ (Fig. 4).
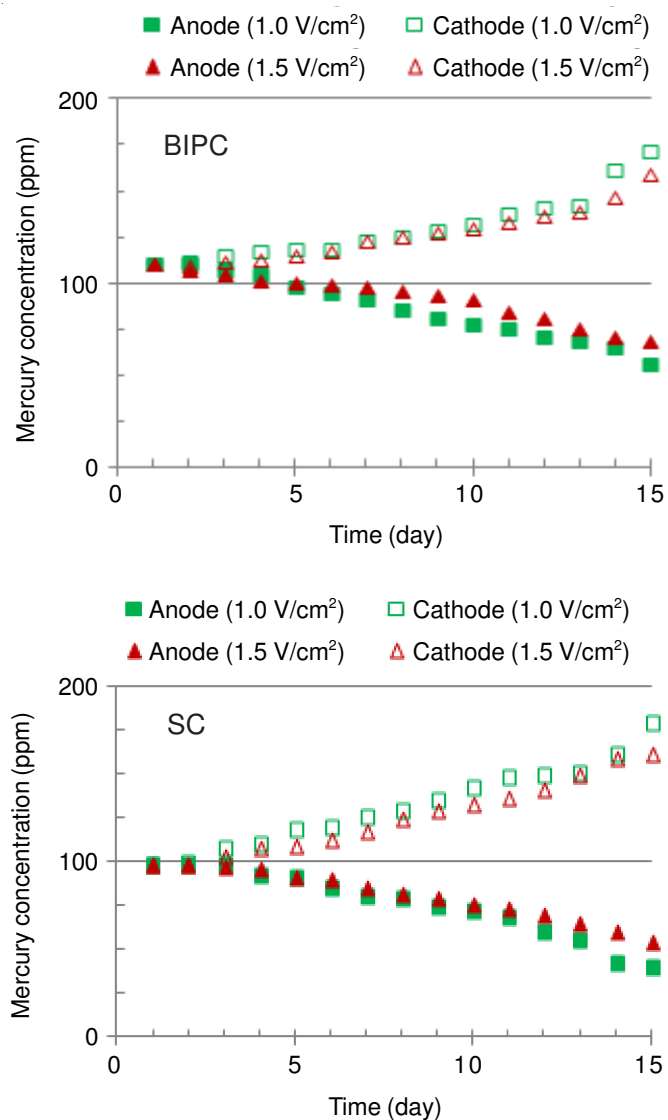

Fig. 3. Changes of the $\mathrm{Hg}$ concentration during the electrokinetics remediation

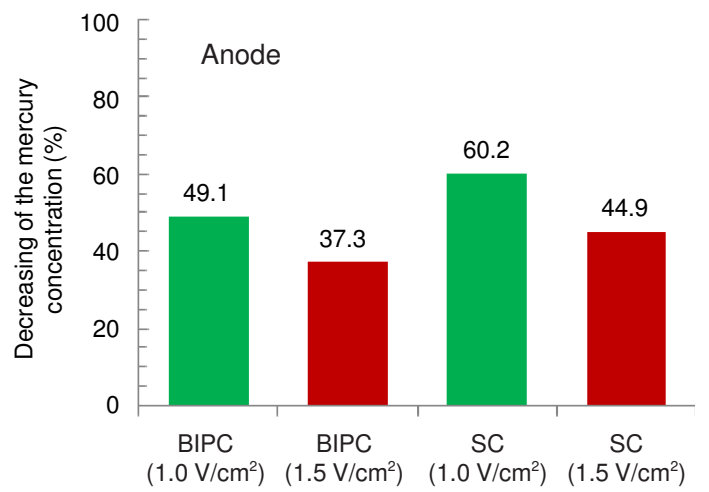

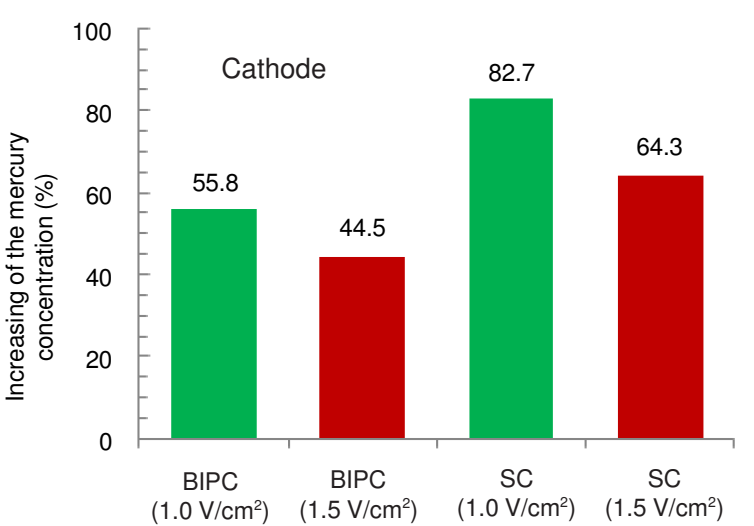

Fig. 4. Hg removal of the Bandar Imam petrochemical complex and sand and clay samples

The removal of the mercury from the sand clay sample was decreased with increasing of the voltage gradient from $1.0-1.5 \mathrm{~V} / \mathrm{cm}^{2}$ (Fig. 3). When the voltage gradient was $1.5 \mathrm{~V} /$ $\mathrm{cm}^{2}$, the $\mathrm{Hg}$ concentration of the anode electrode was decreased to $54 \mathrm{ppm}$ during 15 days. Also the $\mathrm{Hg}$ concentration of the cathode electrode was increased to $161 \mathrm{ppm}$ during this time. So the $\mathrm{Hg}$ concentration in the anode electrode was decreased to $44.9 \%$ while its concentration in the anode electrode was increased to $64.3 \%$.

Electrokinetics remediation of the sand and clay sample has rather low efficiency using water in the cathode reservoir. The reason was low solubility of the $\mathrm{Hg}$ compounds in soil. Furthermore, it was known that soils around the cathode enjoy higher efficiency in the $\mathrm{Hg}$ removal than elsewhere in the cell due to $\mathrm{Hg}^{2+}$ and its transport cathode-ward.

Using the catholyte and giving voltage gradient of $1 \mathrm{~V} /$ $\mathrm{cm}^{2}$, the $\mathrm{Hg}$ concentration of the sand and clay sample was decreased from 98 to $39 \mathrm{ppm}$ (from the cathode away towards the anode). Achieving such high efficiency is the result of the complete solution of $\mathrm{HgI}_{4}{ }^{2-}$ in soil contrary to $\mathrm{Hg}$. Therefore, adding iodide $\left(\mathrm{I}^{-}\right)$to soil leads to the $\mathrm{Hg}$ solution and its better removal from the soil matrix that finally, moves towards the anode.

Higher iodide concentration of the cell increases the combination possibility of $\mathrm{Hg}$ with iodide $\left(\mathrm{I}^{-}\right)$, turning more $\mathrm{Hg}$ into $\mathrm{HgI}_{4}{ }_{4}^{2-}$ compound that leads to increased removal efficiency.

A comparison between the two different voltage gradients of 1.0 and $1.5 \mathrm{~V} / \mathrm{cm}^{2}$ during the treatment of the sand and clay sample is given in Fig. 3. So, $1 \mathrm{~V} / \mathrm{cm}^{2}$ voltage gradient led into higher efficiency than $1.5 \mathrm{~V} / \mathrm{cm}^{2}$ voltage gradient.

The primary concentration of the $\mathrm{Hg}$ in the Bandar Imam petrochemical complex sample was $110 \mathrm{ppm}$. When the voltage gradient was $1 \mathrm{~V} / \mathrm{cm}^{2}$, the $\mathrm{Hg}$ concentration of the anode electrode was decreased to $56 \mathrm{ppm}$ after 15 days. Also the $\mathrm{Hg}$ concentration of the cathode electrode was increased to 171 ppm after 15 days. So the $\mathrm{Hg}$ concentration in the anode electrode was decreased to $49.1 \%$ while its concentration in the anode electrode was increased to $55.8 \%$ (Fig. 4).

The removal of the mercury of the Bandar Imam petrochemical complex sample was decreased with increasing of the voltage gradient from 1.0 to $1.5 \mathrm{~V} / \mathrm{cm}^{2}$ (Fig. 3). When the voltage gradient was $1.5 \mathrm{~V} / \mathrm{cm}^{2}$, the $\mathrm{Hg}$ concentration of the anode electrode was decreased to $69 \mathrm{ppm}$ during 15 days. Also 
the $\mathrm{Hg}$ concentration of the cathode electrode was increased to $159 \mathrm{ppm}$ during this time. So the $\mathrm{Hg}$ concentration in the anode electrode was decreased to $37.3 \%$ while its concentration in the anode electrode was increased to $44.5 \%$.

Difference in the moisture content of the treated samples by higher voltage gradient in a cell was more than that with lower voltage gradients. It was observed that treatment of the SC sample by electrokinetics method using water as evidence in the cathode reservoir has rather low efficiency due to low solubility of the $\mathrm{Hg}$ compounds in soils. This makes electrokinetics treatment difficult. Furthermore, it was demonstrated that removal efficiency is more at the vicinity of cathode than elsewhere within the cell due to the presence of $\mathrm{Hg}^{2+}$ and its movement toward the negative pole (cathode).

Potassium iodide reacts with $\mathrm{Hg}^{2+}$ to form stable complex with the negative charge $\mathrm{HgI}_{4}{ }^{2-}$. The negative charge of $\mathrm{HgI}_{4}{ }^{2-}$ helps its movement toward the anode (positive charge) and being treated easily, leading to decrease of the $\mathrm{Hg}$ content from $98 \mathrm{ppm}$ to $39 \mathrm{ppm}$. Most of the $\mathrm{Hg}$ content turns into $\mathrm{HgI}_{4}{ }^{2-}$ that increases removal efficiency.

Effect of pH on the removal of mercury: The effect of $\mathrm{pH}$ on the removal of mercury is shown in Fig. 5. At the beginning, high current flow is encountered as it is in its initial stage of treatment and large amount of ions exists that helps the electrolysis to produce more $\mathrm{H}^{+}$and $\mathrm{OH}^{-}$. Therefore, $\mathrm{pH}$ of the anode reservoir is less at the beginning than at later stages. Generally speaking, the more amperage through the cell, the more $\mathrm{pH}$ of the cathode solution and thus the less $\mathrm{pH}$ around the anode.
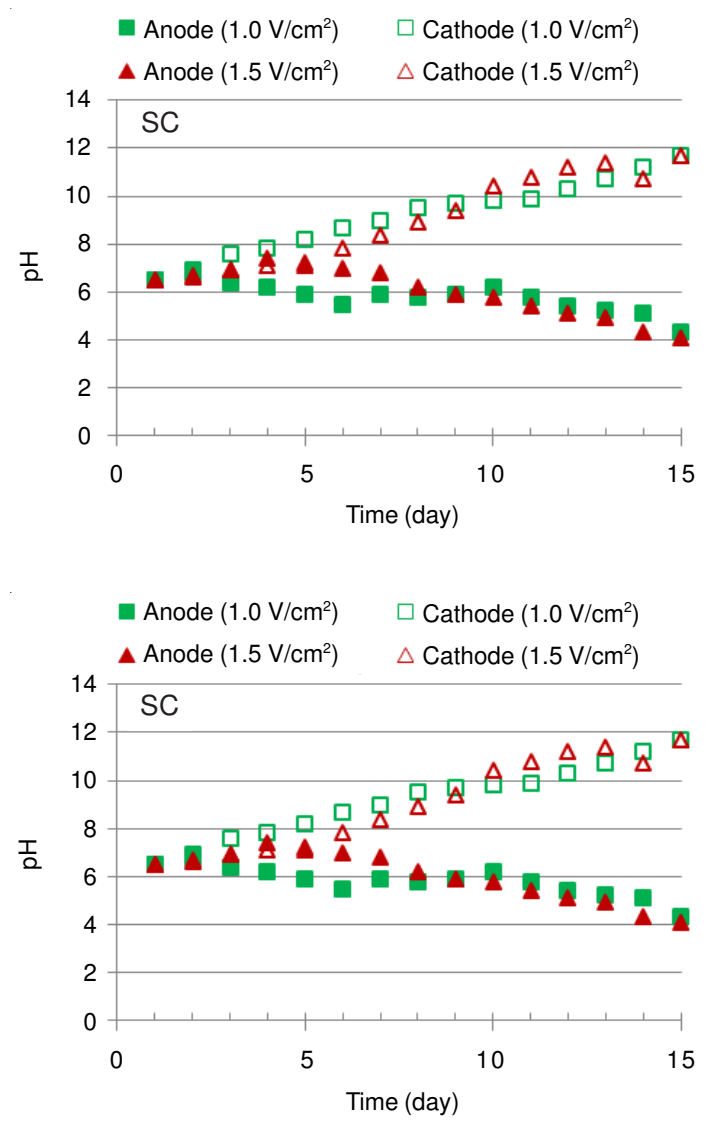

Fig. 5. Changes of the $\mathrm{pH}$ during the electrokinetics remediation
Effect of amperage on the removal of mercury: The effect of amperage on the removal of mercury is shown in Fig. 6. Changes of the amperage in the Bandar Imam petrochemical complex sample are less than in the sand and clay sample because of the soil characteristics. An ionic liquid is prepared with dissolving the salts of the soil in water. When electrical voltage is applied, the initial amperage is high due to high ion concentrations of the soil. The amperage decreases with increasing of the time because the cathions and anions will migrate towards the electrodes. Furthermore, electrolysis products may take part in migrating of the neutralizing ions. The $\mathrm{H}^{+}$ions, moving toward the cathode, are neutralized in the encounter of the $\mathrm{OH}^{-}$ions, resulting in the formation of water. Thus the ions existing in the solution are diluted. The presence of the KI in the soil cause to provides additional ions and thus the amperage is increased. Also the higher voltage gradient is effective on the ions movement because the ions that had been statically fixed in the lower voltage gradient may be move with increasing of the electrical potential.

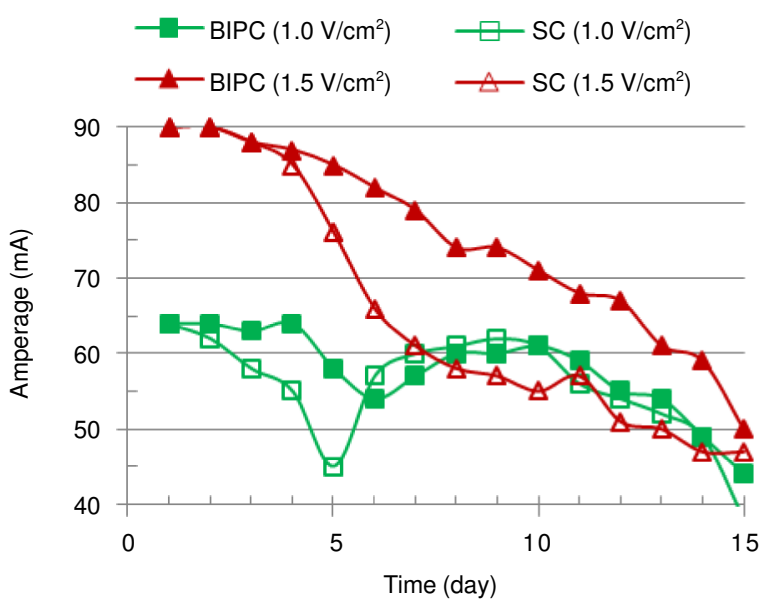

Fig. 6. Changes of the amperage during the electrokinetics remediation

\section{Conclusion}

Heavy metals such as $\mathrm{Hg}$ are among the toxic contaminants, which are often detected in hazardous sites, either in soil or surface water/groundwater. In this research, removal of $\mathrm{Hg}$ from the Bandar Imam petrochemical complex soil sample was studied and the following conclusions were obtained:

The removal of mercury from the sand and clay sample was more than from the Bandar Imam petrochemical complex sample. Using the catholyte and giving the voltage gradient of $1 \mathrm{~V} / \mathrm{cm}^{2}$, the $\mathrm{Hg}$ concentration of the sand and clay sample was decreased from 98 to 39 ppm and that of the Bandar Imam petrochemical complex sample was decreased from 110 to 56 $\mathrm{ppm}$. The removal of mercury was decreased with increasing of the voltage gradient from $1.0-1.5 \mathrm{~V} / \mathrm{cm}^{2}$. Changes of the amperage in the Bandar Imam petrochemical complex sample were less than in the sand and clay sample because of the soil characteristics. By adding water to the soil, the salts existing in it dissolve and an ionic liquid is obtained. When electrical voltage was applied, the initial amperage was high due to the high ion concentrations. 


\section{ACKNOWLEDGEMENTS}

The authors are grateful to Tarbiat Modares University and Chlor-alkali unit of Bandar Imam Petrochemical Complex for their contribution on this research.

\section{REFERENCES}

1. Y.B. Acar and A.N. Alshawabkeh, J. Geotechnol. Eng., 122, 173 (1996).

2. Y.B. Acar, J.T. Hamed, A.N. Alshawabkeh and R.J. Gale, Geotechnique, 44, 239 (1994)

3. V. Pomes, A. Fernandez, N. Costarramone, B. Grano and D. Houi, Colloid. Surf. A, 159, 481 (1999).

4. R. Shrestha, R. Fischer and D. Rahner, Colloid. Surf. A, 222, 261 (2003).

5. C.J. Bruell, B.A. Segall and M.T. Walsh, J. Environ. Eng., 118, 68 (1992).

6. Y.B. Acar, E.E. Ozsu, A.N. Alshawabkeh, M.F. Rabbi and R.J. Gale, Chemtechnology, 26, 40 (1996).

7. H.M. Jacob, AOSTRA (1994).

8. J. Thoming, B.K. Kliem and L.M. Ottosen, Sci. Total Environ., 261, 137 (2000)

9. W. Baeyens and M. Leermakers, Mar. Chem., 60, 257 (1998).
10. K. Kannan, R.G. Smith, R.F. Lee, H.L. Windom, P.T. Heitmuller, J.M. Macauley and J.K. Summers, Arch. Environ. Contam. Toxicol., 34, 109 (1998).

11. J.C. Sferra, P.C. Fuchsman, R.J. Wenning and T.R. Barber, Arch. Environ. Contam. Toxicol., 37, 488 (1999).

12. B.J. Harland, D. Taylor and A. Wither, Sci. Total Environ., 253, 45 (2000).

13. A. Turner, G.E. Millward and S.M. Roux, Int. J. Environ. Sci. Technol., 35, 4648 (2001).

14. S. Grassi and R. Netti, J. Hydrology, 237, 198 (2000).

15. N.S. Bloom and E.A. Crecelius, Mar. Chem., 14, 49 (1983).

16. D. Cossa, J.H. Martin, K. Takayangi and J. Sanjuan, Deep. Sea. Res. II, 44, 712 (1997).

17. S.R. Aston and S.W. Fowler, Sci. Total Environ., 43, 13 (1985).

18. G. Buffoni, M. Bernhard and A. Renzoni, Thalassia. Jugosl., 18, 231 (1982).

19. R. Ferrara, B.E. Maserti and P. Paterno, Toxicol. Environ. Chem., 22, 131 (1989).

20. P. Feng, X.B. Li, G.L. Qiu, L.H. Shang and Z.G. Li, J. Hazard. Mater., 168, 591 (2009).

21. A. Kudo, Y. Fujikawa, S. Miyahara, J. Zheng, H. Takigami, M. Sugahara and T. Muramatsu, Water. Sci. Technol., 38, 187 (1998).

22. M. Harada, Adv. Bioethics, 8, 299 (2005).

23. A. Aghanabati, Published by Geological Survey of Iran (2004).

24. J.M. Giulbert and C.F. Park, W.H. Freeman and Company (1985). 